ISSN 1678-3921

Journal homepage: www.embrapa.br/pab

For manuscript submission and journal contents, access: www.scielo.br/pab
Marines Batalha Moreno Kirinus ${ }^{(1 区)}(3)$, Roberto Pedroso de Oliveira(2) Pricila Santos da Silva(3) Caroline Farias Barreto ${ }^{(1)}$, Marcelo Barbosa Malgarim ${ }^{(1)}$ and Walter dos Santos Soares Filho ${ }^{(4)}$

(1) Universidade Federal de Pelotas, Avenida Eliseu Maciel, s/no, CEP 96900-010 Capão do Leão, RS, Brazil.

E-mail: marinesfaem@gmail.com, carol_fariasb@hotmail.com, malgarim@ufpel.edu.br

(2) Embrapa Clima Temperado, Rodovia BR392, Km 78, s/no, $9^{\circ}$ Distrito, CEP 96010-971 Pelotas, RS, Brazil.

E-mail: roberto.pedroso@embrapa.br

(3) Universidade Estadual de Santa Catarina, Avenida Luís de Camões, № 2.090, CEP 88520-000 Lages, SC, Brazil.

E-mail: pricilassilva@hotmail.com

(4) Embrapa Mandioca e Fruticultura, Rua Embrapa, s/no, CEP 44380-000 Cruz das Almas, BA, Brazil.

E-mail:walter.soares@embrapa.br

$\bowtie$ Corresponding author

Received

August 15, 2017

Accepted

June 13, 2018

How to cite

KIRINUS, M.B.M.; OLIVEIRA, R.P. de; SILVA, P.S. da; BARRETO, C.F.; MALGARIM, M.B. SOARES FILHO, W. dos S. Agronomic performance of 'Valência' orange combined with 13 rootstocks in the state of of Rio Grande do Sul, Brazil. Pesquisa Agropecuária Brasileira, v.54, e00461, 2019. DOI: https://doi. org/10.1590/S1678-3921.pab2019.v54.00461.

\section{Agronomic performance of 'Valência' orange combined with 13 rootstocks in the state of Rio Grande do Sul, Brazil}

\begin{abstract}
The objective of this work was to evaluate the agronomic performance of'Valência' sweet orange (Citrus sinensis) tree, in combination with 13 rootstocks cultivated in soil and climate conditions of the Brazilian state of Rio Grande do Sul. The following agronomic variables were evaluated: scion height and volume, plant production, production efficiency, productivity, fruit diameter, fruit mass, peel mass, juice yield, soluble solids content, titratable acidity, soluble solids:acidity ratio, ascorbic acid, peel color, antioxidant capacity, and phenolic compounds. A randomized complete block experimental design was used, with three replicates and nine plants per plot, in a two-factor arrangement (13 rootstocks and the 2015 and 2016 harvests). The following rootstocks stood out: TSKC $\times$ TRDP-023 for its juice yield (54.0 and 51.7\%), soluble solids:acidity ratio (8.66 and 6.99), and ascorbic acid (49.3 and $51 \mathrm{mg} 100 \mathrm{~g}^{-1}$ ); and the citrandarin 'San Diego', for its higher phenolic-compound content (106.4 and $74.9100 \mathrm{~g}^{-1}$ gallic acid), coloration

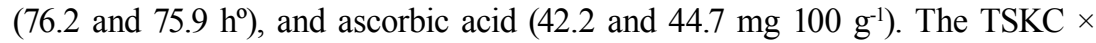
TRDP-026 and TSKC $\times$ CTQT1434-004 rootstocks induce canopy formation and productive precocity in 'Valência' orange trees grown in the southern region of the state of Rio Grande do Sul state, in the first few years of growth.
\end{abstract}

Index terms: Citrus sinensis, bioactive compounds, fruit quality.

\section{Desempenho agronômico de laranja 'Valência' em combinação com 13 porta- enxertos no Rio Grande do Sul, Brasil}

\begin{abstract}
Resumo - O objetivo deste trabalho foi avaliar o desempenho agronômico de laranjeira 'Valência' (Citrus sinensis), em combinação com 13 porta-enxertos cultivados nas condições edafoclimáticas do Rio Grande do Sul. Avaliaramse as seguintes variáveis agronômicas: altura e volume da copa, produção por planta, eficiência produtiva, produtividade, diâmetro dos frutos, massa dos frutos, massa das cascas, rendimento do suco, sólidos solúveis, acidez titulável, relação sólidos solúveis:acidez, ácido ascórbico, coloração da casca, capacidade antioxidante e compostos fenólicos. Utilizou-se um delineamento experimental de blocos ao acaso, com três repetições e nove plantas por parcela, em arranjo bifatorial (13 porta-enxertos e as safras 2015 e 2016). Destacaram-se os portaenxertos: TSKC x TRDP-023, quanto ao rendimento de suco $(54,0$ e 51,7\%), à relação açucar:acidez $\left(8,66\right.$ e 6,99) e ao ácido ascórbico $\left(49,3\right.$ e $\left.51 \mathrm{mg} 100 \mathrm{~g}^{-1}\right)$; e o citrandarin 'San Diego', quanto ao teor de compostos fenólicos (106,4 e 74,9 100 $\mathrm{g}^{-1}$ de ácido gálico), à coloração (76,2 e 75,9 hue) e ao ácido ascórbico (42,2 e 44,7 mg $100 \mathrm{~g}^{-1}$ ). Os porta-enxertos TSKC x TRDP-026 e TSKC x CTQT1434-004 induzem a formação de copa e a precocidade produtiva de laranjeira 'Valência' nos primeiros anos, na região sul do Rio Grande do Sul.
\end{abstract}

Termos para indexação: Citrus sinensis, compostos bioativos, qualidade de frutos. 


\section{Introduction}

Brazil occupies a notable position within global citriculture, with an annual production of 16 million tonnes. Sweet oranges [Citrus sinensis (L.) Osbeck] are particularly notable; and Brazil accounts for 30\% of its global production whose primary focus is juice export (IBGE, 2014). 'Valência' is the main sweet orange cultivated on a global level (Fundecitrus, 2017), and it is highly adapted to the Brazilian state of Rio Grande do Sul (Cunha Sobrinho et al., 2013). Citrus production in the South of Brazil amounts to approximately 1.654 million tonnes, out of which 504 thousand tonnes (27\%) come from Rio Grande do Sul (IBGE, 2014).

Various agronomic characteristics are influenced by the rootstock chosen, such as fruit productivity and quality, nutrient absorption, synthesis and use, plant size and longevity, and tolerance to drought and salinity (Schäfer et al., 2001). Rootstock choice also affects the content of bioactive compounds in citrus fruits (Legua et al., 2014). These compounds exhibit antioxidant properties that are beneficial to human health.

Rootstocks are commonly used in fruit farms for their favorable attributes to scions. However, there is a limited diversity available for citriculture rootstocks within Southern Brazil. The hybrid lemon 'Cravo' ( $C$. limonia Osbeck) holds a notable position in domestic citriculture when used as a rootstock. In Rio Grande do Sul, the main rootstock use is the trifoliate orange [Poncirus trifoliata (L.) Raf.], as it shows and excellent adaptability to the local climate conditions, reduces the size of the scion, increases planting density, and is resistant to diseases, such as gummosis caused by Phytophthora. In addition, it improves fruit productivity and quality (Cunha Sobrinho et al., 2013; Carvalho et al., 2016). Nonetheless, this rootstock species is susceptible to drought. This problem is most evident both in years with drought stress and in very sandy soils, leading to production fluctuations. In some cases, the use of inappropriate rootstocks for a given scion can result in incompatibility issues or gum formation on the graft line, leading to minimally productive and short-lived orange trees (Pompeu Junior \& Blumer, 2014).

The use of hybrid rootstocks is a method to increase the distribution of favorable characteristics within the available citric genetic diversity in Southern Brazil. For instance, hybrid citrandarin rootstocks are used due to their improved ability to tolerate citrus decline and sudden death, immunity to the tristeza virus, and resistance to gummosis (Pompeu Junior \& Blumer, 2014).

Diversifying the variety of scions and rootstocks is significantly important for reducing risks. Fruit farms that restricts the use of the varieties that are available to them are subject to natural, biotic stress (in the form of plagues and diseases), as well as abiotic stress (mainly relating to climate).

The objective of this work was to evaluate the agronomic development of 'Valência' orange trees, combined with 13 rootstocks cultivated in climate and soil conditions of the Brazilian state of Rio Grande do Sul.

\section{Materials and Methods}

The experiment was performed in Monte Bonito (31 $41^{\circ} 47^{\prime \prime} \mathrm{S}, 52^{\circ} 26^{\prime} 24^{\prime \prime} \mathrm{W}$, at $60 \mathrm{~m}$ altitude), a district of Pelotas county, in the state of Rio Grande do Sul, Brazil. 'Valência' orange scions, combined with 13 rootstocks, were evaluated during the 2015 and 2016 harvests. Twelve-month-old seedlings of $40 \mathrm{~cm}$ height were planted in $5.0 \mathrm{~m} \times 4.0 \mathrm{~m}$ spacing and analyzed at four and five years of age. The local soil is moderately deep, with a medium texture sand in the horizon A and clay in the horizon B, and it is classified as Argissolo Vermelho Amarelo (Santos et al., 2006), i.e., Oxisol. According to the Köppen-Geiger classification, the region exhibits a Cfa climate, indicating a humid subtropical climate with hot summers. Climactic data were obtained in an Embrapa experimental station near the fruit farm. The area has $1,590 \mathrm{~mm}$ mean annual precipitation, $18.4^{\circ} \mathrm{C}$ mean annual temperature, and $78.8 \%$ relative annual air humidity (INMET, 2016).

A randomized complete block experimental design was employed, with three replicates and nine plants per plot, and a bifactorial arrangement with 13 rootstocks over the 2015 and 2016 harvests. The three central plants of each block were evaluated. The rootstocks consisted of hybrids selected by the program for the improvement of Citrus genetics of Embrapa Mandioca e Fruticultura, in Bahia state, Brazil (Table 1).

The following vegetative characteristics were evaluated for: scion height $(\mathrm{H})$, measured with a graduated ruler from the intersection point of stalk and root until the scion apex, expressed in meters; scion volume $(\mathrm{V})$, obtained by the formula $\mathrm{V}=\pi / 6 \times \mathrm{H} \times(\mathrm{d} 1$ x d2), provided by Fallahi \& Rodney (1992), in which

Pesq. agropec. bras., Brasília, v.54, e00461, 2019

DOI: 10.1590/S1678-3921.pab2019.v54.00461 
$\mathrm{d}$ represents the diameter of the scion measured both longitudinally (d1) and perpendicularly to the line of the plant (d2); plant productivity, obtained by counting and weighing the collected fruit (kg per plant); production efficiency, corresponding to the number of fruit per unit of scion volume, obtained with the formula $\mathrm{EP}=$ (number of fruit $\times$ fruit mass) / V (expressed in $\mathrm{kg} \mathrm{m}^{-3}$ ); and fruit farm productivity, obtained from fruit mass and production area $\left(\mathrm{Mg} \mathrm{ha}^{-1}\right)$.

Fruit were collected at the maturation stage, at the ready-for-sale point 10 on the scale adapted from Barbasso et al. (2005), which randomly considers the four quadrants of the scion. The collected fruit were placed in cleaned and disinfected plastic boxes and then transported to the laboratory of the Universidade Federal de Pelotas. There, fruit undergone a pre-selection, and damaged or otherwise affected fruit were discarded. In this way, fruit were effectively standardized. From the selected fruit, 20 ones from each replicate were assigned to analysis, which totaled three replicates per combination of rootstocks and scions.

The following physical characteristics were evaluated: fruit diameter $(\mathrm{mm})$, measured with a digital caliper; mean mass (g) of whole fruit and peel, measured with a semi-analytical balance; juice yield (\%), determined by taking the ratio of the whole fruit mass and pulp mass; peel color, identified with a Minolta CR-300 colorimeter (Konica Minolta, Ramsey, NJ, USA) and described using the Cielab color space; and chromatic tonality $\left(h^{\circ}\right)$, calculated as the arctangent of $b^{*} / a^{*}$ and expressed in degrees.

The following chemical characteristics were evaluated: soluble solids content ( ${ }^{\circ}$ Brix), which was quantified using a PAL-1 digital refractometer (Atago, Bellevue, WA, USA); titratable acid, determined by titrating $10 \mathrm{~mL}$ of fruit juice, added to $90 \mathrm{~mL}$ of distilled water at $8.1 \mathrm{pH}$, with a digital burette containing a $0.1 \mathrm{~N}$ solution of sodium hydroxide, and expressed as a percentage of citric acid, in line with AOAC (Horwitz \& Latimer Jr., 2005); the ratio of soluble solids to titratable acids, obtained by following the analytic manual of Instituto Adolfo Lutz (Zenebon et al., 2008); and ascorbic acid content, quantified using the official AOAC method (Horwitz \& Latimer Jr., 2005) by oxidative titration with 2,6-dichlorophenolindophenol to the point of the initial conversion of the solution to pink (mm ascorbic acid $100 \mathrm{~g}^{-1}$ sample (Jacobs, 1958; Leme Junior \& Malavolta, 1950).

The following phytochemical characteristics were evaluated: antioxidant capacity ( $\mu \mathrm{g}$ Trolox equivalent $\mathrm{g}^{-1}$ juice), determined by spectrophotometry using a method adapted from Brand-Williams et al. (1995); and total phenolic compounds $(\mathrm{mL}$ gallic acid equivalent $100 \mathrm{~g}^{-1}$ juice, quantified using the Folin-Ciocalteu reagent in line with the method described by Swain \& Hillis (1959).

Table 1. Description of citrus rootstocks used with 'Valência' orange (Citrus sinensis) scions in the 2015 and 2016 harvests, in the municipality of Pelotas, in the state of Rio Grande do Sul, Brazil.

\begin{tabular}{|c|c|}
\hline Rootstock & Scientific description \\
\hline TSKC $\times$ CTQT 1439-035 & $\begin{array}{l}\text { ['Sunki' mandarin, common, C. sunki (Hayata) hort. ex Tanaka] } \times \text { [citrangequat 'Thomasville' [kumquat 'Oval' or 'Nagami' } \\
\text { Fortunella margarita (Lour.) 'Swingle' selection } 1439 \times \text { citrange }(\text { C. sinensis } \times \text { P. trifoliata) } \text { 'Willits' selection 035] }\end{array}$ \\
\hline TSKC $\times$ TRDP-026 & ['Sunki' mandarin, common, C. sunki (Hayata) hort. ex Tanaka] $\times[$ P. trifoliata selection diploid selection 026] \\
\hline HTR-206 & Trifoliate hybrid selection 206 \\
\hline HTR-208 & Trifoliate hybrid selection 208 \\
\hline TSKFL $\times$ CTTR-006 & ['Sunki' mandarin, Florida selection, C. sunki (Hayata)] $\times$ [citrange 'Troyer' C. sinensis (L.) Osbeck selection 006] \\
\hline TSKC $\times$ CTRK-001 & $\begin{array}{c}\text { ['Sunki' mandarin, common, } C \text {. sunki (Hayata) hort. ex Tanaka] } \times[\text { citrange 'Rusk' C. sinensis (L.) Osbeck } \times \text { C. trifoliata } \\
\text { selection 001] }\end{array}$ \\
\hline TSKC $\times$ CTTR-028 & ['Sunki' mandarin, common, C. sunki (Hayata) hort. ex Tanaka] $\times$ [citrange 'Troyer' C. sinensis (L.) Osbeck selection 028] \\
\hline LVK $\times$ LCR-010 & ['Volkameriano' lemon C. volkameriana V. Ten. \& Pasq.] × ['Cravo' lemon C. limonia Osbeck selection 010] \\
\hline TSKC $\times$ TRBK-007 & ['Sunki' mandarin, common, C. sunki (Hayata) hort. ex Tanaka] × [P. trifoliata 'Benecke' selection 007] \\
\hline TSKC $\times$ CTQT 1434-004 & $\begin{array}{l}\text { ['Sunki' mandarin, common, Citrus sunki (Hayata) hort. ex Tanaka] } \times[\text { citrangequat 'Thomasville' [kumquat 'Oval' or } \\
\text { 'Nagami' Fortunella margarita (Lour.) 'Swingle' selection } 1434 \times \text { citrange }(\text { C. sinensis } \times \text { Poncirus trifoliata) 'Willits' } \\
\text { selection 004] }\end{array}$ \\
\hline HTR-207 & Trifoliate hybrid selection 207 \\
\hline TSKC $\times$ TRDP-023 & ['Sunki' mandarin, common, C. sunki (Hayata) hort. ex Tanaka] $\times[$ P. trifoliata selection diploid selection 023] \\
\hline Citrandarin San Diego & [C. sunki] $\times[$ P. trifoliata 'Swingle' selection 314] \\
\hline
\end{tabular}


Data were analyzed for normality and homoscedasticity, using the Shapiro-Wilk and Hartley tests, respectively. Afterward, data were subjected to the analysis of variance at 5\% probability. When significant, the Scott-Knott test was performed, at $5 \%$ probability, in order to compare the grouping of the means.

\section{Results and Discussion}

Rootstocks TSKC $\times$ TRDP-023, TSKC $\times$ TRDP026, HTR-206, TSKC $\times$ CTTR-028, and citrandarin 'San Diego' provided a significant difference for plant height. These rootstocks favored a greater development of 'Valência' scion in comparison to other rootstocks (Table 2).

The trifoliate hybrid HTR-207 showed the lowest height $(1.37 \mathrm{~m})$. This indicates the potential of this species to be used as a dwarfing rootstock, thereby allowing of fruit farms with a greater plant density than usual ones. These kind of rootstocks are of significant interest due to the practicality they offer for fruit farm management (Pompeu Junior \& Blumer, 2009).

In a study performed in the Bahia state, França et al. (2016) analyzed 'Tuxpan Valência' orange trees at four and eight years of age which had been combined with 14 rootstocks. They measured $2.20 \mathrm{~m}$ mean height, ranging from $1.40 \mathrm{~m}$ for TSKFL $\times$ CTSW-049 hybrid rootstock to $2.80 \mathrm{~m}$ for 'Indio' citrandarin rootstock.

The most rootstocks studied herein increased the scion volume over the evaluation period, with the most notable performance in the 2016 harvest attributed to HTR-206 and TSKC $\times$ CTTR-028.

Rootstocks TSKC $\times$ TRDP-026, HTR-206, TSKC $\times$ CTTR-028, and TSKC $\times$ CTQT1434-004 provided the most favorable fruit productivity values per plant in their fifth year of age, with values of 14.6, 17.4, 14.0, and $16.8 \mathrm{~kg}$ per plant (Table 3), respectively. This may be the result of the climactic conditions in the South region of Brazil during the evaluated period, as the mean temperature and rainfall were $18.4^{\circ} \mathrm{C}$ and 1,590 $\mathrm{mm}$, respectively. However, in their study of 'Tuxpan

Table 2. Scion height and longitudinal (d1) and perpendicular (d2) diameters to the line of the plant for 'Valência' orange (Citrus sinensis) combined with 13 rootstocks in the 2015 and 2016 harvests, in the municipality of Pelotas, in the state of Rio Grande do Sul, Brazil ${ }^{(1)}$.

\begin{tabular}{|c|c|c|c|c|c|c|}
\hline \multirow[t]{2}{*}{ Rootstock } & \multicolumn{2}{|c|}{ Height (m) } & \multicolumn{2}{|c|}{$\mathrm{d} 1(\mathrm{~m})$} & \multicolumn{2}{|c|}{$\mathrm{d} 2(\mathrm{~m})$} \\
\hline & $2015 \mathrm{~B}$ & $2016 \mathrm{~A}$ & $2015 \mathrm{~B}$ & $2016 \mathrm{~A}$ & $2015 \mathrm{~B}$ & $2016 \mathrm{~A}$ \\
\hline TSKC $\times$ CTQT1439-035 & $1.68 \mathrm{c}$ & $1.96 \mathrm{c}$ & $1.62 \mathrm{~b}$ & $2.05 \mathrm{~b}$ & $1.63 \mathrm{c}$ & $1.86 \mathrm{c}$ \\
\hline TSKC $\times$ TRDP-026 & $2.09 \mathrm{a}$ & $2.43 \mathrm{a}$ & $1.76 \mathrm{~b}$ & $2.23 b$ & $1.86 \mathrm{a}$ & $2.26 \mathrm{a}$ \\
\hline HTR-206 & $2.21 \mathrm{a}$ & $2.66 \mathrm{a}$ & $2.02 \mathrm{a}$ & $2.60 \mathrm{a}$ & $1.88 \mathrm{a}$ & $2.46 \mathrm{a}$ \\
\hline HTR-208 & $1.95 \mathrm{~b}$ & $2.30 \mathrm{~b}$ & $1.79 \mathrm{~b}$ & $2.33 b$ & $1.71 \mathrm{a}$ & $2.48 \mathrm{a}$ \\
\hline TSKFL $\times$ CTTR -006 & $1.81 \mathrm{c}$ & $1.92 \mathrm{c}$ & $1.67 \mathrm{~b}$ & $2.29 \mathrm{~b}$ & $1.64 \mathrm{~b}$ & $2.16 \mathrm{~b}$ \\
\hline TSKC $\times$ CTRK -001 & $2.01 \mathrm{~b}$ & $2.22 b$ & $1.80 \mathrm{~b}$ & $2.32 b$ & $1.79 \mathrm{a}$ & $2.31 \mathrm{a}$ \\
\hline TSKC $\times$ CTTR-028 & $2.11 \mathrm{a}$ & $2.75 \mathrm{a}$ & $2.04 \mathrm{a}$ & $2.63 \mathrm{a}$ & $1.94 \mathrm{a}$ & $2.52 \mathrm{a}$ \\
\hline LVK $\times$ LCR -010 & $2.02 \mathrm{~b}$ & $2.21 \mathrm{~b}$ & $1.82 \mathrm{~b}$ & $2.16 \mathrm{~b}$ & $1.78 \mathrm{~b}$ & $2.07 \mathrm{~b}$ \\
\hline TSKC $\times$ TRBK-007 & $2.02 \mathrm{~b}$ & $2.32 \mathrm{~b}$ & $1.86 \mathrm{a}$ & $2.56 \mathrm{a}$ & $2.03 \mathrm{a}$ & $2.44 \mathrm{a}$ \\
\hline TSKC $\times$ CTQT1434-004 & $1.84 \mathrm{c}$ & $2.11 \mathrm{c}$ & $1.84 \mathrm{~b}$ & $2.18 \mathrm{~b}$ & $1.88 \mathrm{~b}$ & $1.99 \mathrm{~b}$ \\
\hline HTR-207 & $1.35 \mathrm{~d}$ & $1.39 \mathrm{~d}$ & $2.21 \mathrm{c}$ & $1.56 \mathrm{c}$ & $1.27 \mathrm{~d}$ & $1.59 \mathrm{~d}$ \\
\hline TSKC $\times$ TRDP -023 & $2.14 \mathrm{a}$ & $2.58 \mathrm{a}$ & $2.07 \mathrm{a}$ & $2.44 a$ & $1.84 \mathrm{a}$ & $2.33 \mathrm{a}$ \\
\hline Citrandarin San Diego & $2.08 \mathrm{a}$ & $2.48 \mathrm{a}$ & $1.97 \mathrm{a}$ & $2.52 \mathrm{a}$ & $1.95 \mathrm{a}$ & $2.41 \mathrm{a}$ \\
\hline Mean & 1.94 & 2.25 & 1.81 & 2.29 & 1.78 & 2.22 \\
\hline General mean & \multicolumn{2}{|c|}{2.09} & \multicolumn{2}{|c|}{2.05} & \multicolumn{2}{|c|}{2.00} \\
\hline Coefficient of variation (\%) & \multicolumn{2}{|c|}{9.5} & \multicolumn{2}{|c|}{11.3} & \multicolumn{2}{|c|}{12.0} \\
\hline \multirow{3}{*}{$\begin{array}{c}\text { rootstock } \times \text { harvest } \\
\text { rootstock }\end{array}$} & \multicolumn{2}{|c|}{$96.62 * *$} & \multicolumn{2}{|c|}{$133.27 * *$} & \multicolumn{2}{|c|}{$173.99 * *$} \\
\hline & \multicolumn{2}{|c|}{$23.96^{* *}$} & \multicolumn{2}{|c|}{$9.39 * *$} & \multicolumn{2}{|c|}{$12.70 * *$} \\
\hline & \multicolumn{2}{|c|}{$1.70^{\mathrm{ns}}$} & \multicolumn{2}{|c|}{$1.39^{\mathrm{ns}}$} & \multicolumn{2}{|c|}{$0.93^{\text {ns }}$} \\
\hline
\end{tabular}

${ }^{(1)}$ Values followed by equal letters, lowercase in the columns and uppercase in the rows, do not differ by the Scott-Knott's test, at $5 \%$ probability. ${ }^{(2)} \mathrm{F}$, analysis of variance. ${ }^{\mathrm{n}}$ Nonsignificant. *, **Significant at 5 and $1 \%$ probability, respectively. 
Valência' orange trees in the state of Bahia, França et al. (2016) found fruit productivity values of 10.2, 8.4, 11.2 , and $15.1 \mathrm{~kg}$ for five-year-old plants with rootstocks TSKFL $\times$ CTTR, LVK $\times$ LVA, TSKC $\times($ LCR $\times$ TR $)$, and 'Indio' citrandarin, respectively.

Rootstocks TSKC $\times$ CTQT1434-004 and HTR-207 yielded significant increases in production efficiency, both in 2015 and 2016 harvests, with final values of, respectively, 2.1 and $3.4 \mathrm{~kg} \mathrm{~m}^{-3}$, and 3.1 and $2.4 \mathrm{~kg} \mathrm{~m}^{-3}$ (Table 3). These results suggest that these rootstocks induce precocity in fruit production. In addition, the hybrids TSKC $\times$ TRDP-026, HTR-206, HTR-208, and TSKC $\times$ TRDP-023 showed higher-production efficiency values specifically in the 2016 harvest. This is most likely the result of greater vegetative growth during the 2015 season, which led to greater production in the following year.

However, the first harvest showed no difference for productivity between the rootstocks due to plant precocity, and had an average value of $2.0 \mathrm{Mg} \mathrm{ha}^{-1}$. The rootstock TSKC $\times$ CTQT1434-004 provided $3.0 \mathrm{Mg}$ $\mathrm{ha}^{-1}$, which is the highest-productivity value (Table 3 ).
Meanwhile, in the 2016 harvest, the rootstocks that showed the highest-productivity values were HTR-206 $\left(8.7 \mathrm{Mg} \mathrm{ha}^{-1}\right)$, TSKC $\times$ CTQT1434-004 $\left(8.4 \mathrm{Mg} \mathrm{ha}^{-1}\right)$, TSKC $\times$ TRDP-026 $\left(7.3 \mathrm{Mg} \mathrm{ha}^{-1}\right)$, TSKC $\times$ CTTR-028 (7.0 Mg ha-1), and HTR-208 (6.7 $\left.\mathrm{Mg} \mathrm{ha}^{-1}\right)$.

As to fruit diameter, the rootstocks that provided the largest values were TSKC $\times$ CTTR-028 (74.9 to $75.0 \mathrm{~mm})$, LVR $\times$ LCR-010 $(77.9$ to $77.5 \mathrm{~mm})$, TSKC $\times$ TRBK-007 (75.9 to $76.9 \mathrm{~mm})$, TSKC $\times$ CTQT1434004 (75.9 to $78.3 \mathrm{~mm}$ ), and HTR-207 (77.4 to $79.5 \mathrm{~mm}$ ) (Table 4).

The hybrids HTR-07, TSKC $\times$ CTQT1434-004, and TSKFL $\times$ CTTR-006 provided an increased fruit mass across harvests, providing the highest values in 2016 (Table 4). In a comparison, Carvalho et al. (2016) found that rootstocks HTR-207, LVK $\times$ LCR-030, and LVK $\times$ LCR-038, when grafted with four-year-old 'Pera CNPMF-D6', showed fruit mass values of 193, 170, and $220 \mathrm{~g}$, respectively, in their study in the Tabuleiros Costeiros region of Sergipe state, Brazil.

In the first season, juice yield varied between the different rootstock combinations (Table 4), with TSKC

Table 3. Vegetative characteristics of 'Valência' orange (Citrus sinensis) combined with 13 rootstocks, in the 2015 and 2016 harvests, in the municipality of Pelotas, in the state of Rio Grande do Sul, Brazil(1).

\begin{tabular}{|c|c|c|c|c|c|c|c|c|}
\hline \multirow[t]{2}{*}{ Rootstock } & \multicolumn{2}{|c|}{$\begin{array}{c}\text { Scion volume } \\
\left(\mathrm{m}^{3}\right)\end{array}$} & \multicolumn{2}{|c|}{$\begin{array}{l}\text { Plant production } \\
\left(\text { kg plant }^{-1}\right)\end{array}$} & \multicolumn{2}{|c|}{$\begin{array}{l}\text { Production efficiency } \\
\qquad\left(\mathrm{kg} \mathrm{m}^{-3}\right)\end{array}$} & \multicolumn{2}{|c|}{$\begin{array}{l}\text { Productivity } \\
\left(\mathrm{Mg} \mathrm{ha}^{-1}\right)\end{array}$} \\
\hline & 2015 & 2016 & 2015 & 2016 & 2015 & 2016 & 2015 & 2016 \\
\hline TSKC $\times$ CTQT1439-035 & $2.4 \mathrm{bB}$ & $4.0 \mathrm{aC}$ & $4.8 \mathrm{aA}$ & $6.9 \mathrm{aC}$ & $1.6 \mathrm{cA}$ & $1.7 \mathrm{cA}$ & $2.4 \mathrm{aA}$ & $3.5 \mathrm{aC}$ \\
\hline TSKC $\times$ TRDP-026 & $3.6 \mathrm{bA}$ & $6.5 \mathrm{aB}$ & $4.9 \mathrm{bA}$ & $14.6 \mathrm{aA}$ & $1.3 \mathrm{cB}$ & $2.4 \mathrm{bA}$ & $2.5 \mathrm{bA}$ & $7.3 \mathrm{aA}$ \\
\hline HTR-206 & $4.4 \mathrm{bA}$ & $9.0 \mathrm{aA}$ & $3.3 \mathrm{bA}$ & $17.4 \mathrm{aA}$ & $0.8 \mathrm{cB}$ & $2.0 \mathrm{cA}$ & $1.7 \mathrm{bA}$ & $8.7 \mathrm{aA}$ \\
\hline HTR-208 & $3.2 \mathrm{bA}$ & $6.9 \mathrm{aB}$ & $3.9 \mathrm{bA}$ & $13.5 \mathrm{aA}$ & $1.2 \mathrm{cB}$ & $1.9 \mathrm{cA}$ & $1.9 \mathrm{bA}$ & $6.7 \mathrm{aA}$ \\
\hline TSKFL $\times$ CTTR -006 & $2.6 \mathrm{bB}$ & $5.1 \mathrm{aC}$ & $4.6 \mathrm{aA}$ & $8.2 \mathrm{aB}$ & $1.5 \mathrm{cA}$ & $1.7 \mathrm{cA}$ & $2.3 \mathrm{aA}$ & $4.1 \mathrm{aB}$ \\
\hline TSKC $\times$ CTRK-001 & $3.4 \mathrm{bA}$ & $6.3 \mathrm{aB}$ & $4.9 \mathrm{bA}$ & $10.2 \mathrm{aB}$ & $1.4 \mathrm{cA}$ & $1.6 \mathrm{cA}$ & $2.5 \mathrm{bA}$ & $5.1 \mathrm{aB}$ \\
\hline TSKC $\times$ CTTR- 028 & $4.3 \mathrm{bA}$ & $9.6 \mathrm{aA}$ & $3.9 \mathrm{bA}$ & $14.0 \mathrm{aA}$ & $0.9 \mathrm{cA}$ & $1.5 \mathrm{cA}$ & $2.0 \mathrm{bA}$ & $7.0 \mathrm{aA}$ \\
\hline LVK $\times$ LCR -010 & $3.4 \mathrm{bA}$ & $5.2 \mathrm{aC}$ & $5.1 \mathrm{aA}$ & $6.6 \mathrm{aC}$ & $1.5 \mathrm{cA}$ & $1.3 \mathrm{cA}$ & $2.6 \mathrm{aA}$ & $3.3 \mathrm{aC}$ \\
\hline TSKC $\times$ TRBK-007 & $4.0 \mathrm{bA}$ & 7.6aB & $5.9 \mathrm{aA}$ & $8.6 \mathrm{aB}$ & $1.6 \mathrm{cA}$ & $1.1 \mathrm{cA}$ & $3.0 \mathrm{aA}$ & $4.3 \mathrm{aB}$ \\
\hline TSKC $\times$ CTQT1434-004 & $3.3 \mathrm{bA}$ & $4.8 \mathrm{aC}$ & $6.2 \mathrm{bA}$ & $16.8 \mathrm{aA}$ & $2.1 \mathrm{bA}$ & $3.4 \mathrm{aA}$ & $3.1 \mathrm{bA}$ & $8.4 \mathrm{aA}$ \\
\hline HTR-207 & $1.0 \mathrm{aC}$ & $1.8 \mathrm{aD}$ & $3.8 \mathrm{aA}$ & $5.1 \mathrm{aC}$ & $3.1 \mathrm{aA}$ & $2.4 \mathrm{bA}$ & $1.9 \mathrm{aA}$ & $2.1 \mathrm{aC}$ \\
\hline TSKC $\times$ TRDP -023 & $4.2 \mathrm{bA}$ & $7.6 \mathrm{aB}$ & $4.0 \mathrm{bA}$ & $11.0 \mathrm{aB}$ & $0.9 \mathrm{cB}$ & $1.4 \mathrm{cA}$ & $2.0 \mathrm{bA}$ & $5.5 \mathrm{aB}$ \\
\hline Citrandarin San Diego & $4.2 \mathrm{bA}$ & $7.9 \mathrm{aB}$ & $4.4 \mathrm{bA}$ & $8.5 \mathrm{aB}$ & $1.1 \mathrm{cA}$ & $1.6 \mathrm{cA}$ & $2.2 \mathrm{bA}$ & $4.2 \mathrm{aB}$ \\
\hline Mean & 3.43 & 6.30 & 4.50 & 11.10 & 1.46 & 1.85 & 2.31 & 5.52 \\
\hline Coefficient of variation (\%) & \multicolumn{2}{|c|}{24} & \multicolumn{2}{|c|}{41} & \multicolumn{2}{|c|}{47} & \multicolumn{2}{|c|}{41} \\
\hline \multirow{3}{*}{$\begin{array}{c}\text { rootstock } \times \text { harvest } \\
\text { rootstock }\end{array}$} & \multicolumn{2}{|c|}{$247.15^{* *}$} & \multicolumn{2}{|c|}{$162.6^{* *}$} & \multicolumn{2}{|c|}{$8.06^{* *}$} & \multicolumn{2}{|c|}{$162.87 * *$} \\
\hline & \multicolumn{2}{|c|}{$19.01 * *$} & \multicolumn{2}{|c|}{$4.76^{* *}$} & \multicolumn{2}{|c|}{$1.87 *$} & \multicolumn{2}{|c|}{$4.76^{* *}$} \\
\hline & \multicolumn{2}{|c|}{$3.48 * *$} & \multicolumn{2}{|c|}{$4.91 * *$} & \multicolumn{2}{|c|}{$5.61 * *$} & \multicolumn{2}{|c|}{$4.90 * *$} \\
\hline
\end{tabular}

(1)Values followed by equal letters, lowercase in the columns and uppercase in the rows, do not differ, by the Scott-Knott's test, at $5 \%$ probability. ${ }^{(2)} \mathrm{F}$, analysis of variance. ${ }^{\mathrm{n}} \mathrm{N}$ Non significant. *, ${ }^{* *}$ Significant at 5 and $1 \%$ probability, respectively. 
$\times$ CTQT1439-035 (56.3\%), LVK × LVR-010 (58.7\%), and TSKC $\times$ TRDP-023 (54.0\%) providing the highest values. In the second season, HTR-207 and TSKC $\times$ TRBK-007 provided the greatest-yield increase, with mean values of 59.1 and $54.8 \%$, respectively. Comparatively, in Bahia state, França et al. (2016) found $51 \%$ juice yield for TSKC $\times$ CTSW-028 and TSKFL $\times$ CTTR-017, as well as $42 \%$ for TSKFL $\times$ CTSW-049, from the 2010 to 2014 seasons.

Total soluble solids varied significantly across the evaluation years (Table 4). In the first year, the highest values were provided by TSKC $\times$ TRDP-023 $\left(11.8^{\circ} \mathrm{Bx}\right)$ and the citrandarin 'San Diego' $\left(11.4^{\circ} \mathrm{Bx}\right)$, whereas in the second year, the highest values were observed for HTR$207\left(10.4^{\circ} \mathrm{Bx}\right)$, which meet the minimum requirements for total soluble solids. In a study performed in Paraná state, Brazil, Auler et al. (2008) found 10.4 and $11.9^{\circ} \mathrm{Bx}$ when using 'Cravo' lemon and 'Troyer' citrange, respectively, as rootstocks for 'Valência' oranges. However, França et al. (2016) found 10.8 and $11.3^{\circ} \mathrm{Bx}$ which were the highest values for TSKC $\times$ CTSW-028 and TSKFL $\times$ CTTR-017, respectively, over the course of four harvests in their aforementioned study.

The rootstock TSKC $\times$ CTQT1439-035 yielded plants with the most acidic oranges; citric acidity was measured at about $1.6 \%$ over both seasons (Table 4). However, HTR-206, TSKC $\times$ CTTR-028, TSKC $\times$ TRBK-007, TSKC $\times$ CTQT1434-004, TSKC $\times$ TRDP023, citrandarin 'San Diego', and LVK $\times$ LCR-010 had the lowest values for acidity, and the latter one showed a minimum of $1.17 \%$.

Alternatively, França et al. (2016) found acidity values below $1 \%$ in their aforementioned study. Likewise, Auler et al. (2009) found values lower than $1.2 \%$ in 'Valência' oranges produced in the northeastern Paraná state, in the first three harvest years of their experiment.

The soluble solid/acidity ratio was high, particularly for HTR-206, TSKC $\times$ CTTR-028, LVK $\times$ LCR-010, TSKC $\times$ CTQT1434-004, TSKC $\times$ TRDP-023, and citrandarin 'San Diego' rootstocks (Table 5). Meanwhile, the TSKC $\times$ CTQT1439-035 hybrid showed the lowest value for this ratio.

Table 4. Physicochemical characteristics of 'Valência' orange (Citrus sinensis) combined with 13 rootstocks for 2015 and 2016 harvests, in the municipality of Pelotas, in the state of Rio Grande do Sul, Brazil ${ }^{(1)}$.

\begin{tabular}{|c|c|c|c|c|c|c|c|c|c|c|c|c|}
\hline \multirow[t]{2}{*}{ Rootstock } & \multicolumn{2}{|c|}{$\begin{array}{l}\text { Fruit diameter } \\
\quad(\mathrm{mm})\end{array}$} & \multicolumn{2}{|c|}{$\begin{array}{l}\text { Fruit mass } \\
(\mathrm{g})\end{array}$} & \multicolumn{2}{|c|}{$\begin{array}{l}\text { Peel mass } \\
(\mathrm{g})\end{array}$} & \multicolumn{2}{|c|}{$\begin{array}{l}\text { Juice yield } \\
(\%)\end{array}$} & \multicolumn{2}{|c|}{$\begin{array}{l}\text { Soluble solids } \\
\quad\left({ }^{\circ} \mathrm{Bx}\right)\end{array}$} & \multicolumn{2}{|c|}{$\begin{array}{l}\text { Titratable acid } \\
\text { (\% citric acid) }\end{array}$} \\
\hline & 2015 & 2016 & 2015 & 2016 & 2015 & 2016 & 2015 & 2016 & 2015 & 2016 & 2015 & 2016 \\
\hline TSKC $\times$ CTQT1439-035 & $70.0 \mathrm{aB}$ & $70.5 \mathrm{aB}$ & $165 \mathrm{aB}$ & $172 \mathrm{aC}$ & $92 \mathrm{aB}$ & $91 \mathrm{aD}$ & $56.3 \mathrm{aA}$ & $52.8 \mathrm{aA}$ & $9.9 \mathrm{aC}$ & $8.6 \mathrm{bC}$ & $1.61 \mathrm{aA}$ & $1.60 \mathrm{aA}$ \\
\hline TSKC $\times$ TRDP-026 & $66.1 \mathrm{aC}$ & $67.3 \mathrm{aB}$ & $151 \mathrm{aB}$ & $145 \mathrm{aC}$ & $70 \mathrm{aC}$ & $69 \mathrm{aE}$ & $46.7 \mathrm{aB}$ & $47.6 \mathrm{aA}$ & $10.5 \mathrm{aB}$ & $9.6 \mathrm{bB}$ & $1.48 \mathrm{aA}$ & $1.18 \mathrm{bB}$ \\
\hline HTR-206 & $66.8 \mathrm{aC}$ & $69.1 \mathrm{aB}$ & $152 \mathrm{aB}$ & $157 \mathrm{aC}$ & $64 \mathrm{aC}$ & $76 \mathrm{aE}$ & $42.2 \mathrm{aB}$ & $48.2 \mathrm{aA}$ & $9.7 \mathrm{aC}$ & $9.5 \mathrm{aB}$ & $1.28 \mathrm{aB}$ & $1.30 \mathrm{aB}$ \\
\hline HTR-208 & $67.0 \mathrm{aC}$ & $69.6 \mathrm{aB}$ & $141 \mathrm{aB}$ & $160 \mathrm{aC}$ & $57 \mathrm{bC}$ & $73 \mathrm{aE}$ & $40.9 \mathrm{aB}$ & $45.6 \mathrm{aA}$ & $10.3 \mathrm{aB}$ & $9.6 \mathrm{aB}$ & $1.47 \mathrm{aA}$ & $1.26 \mathrm{bB}$ \\
\hline TSKFL $\times$ CTTR -006 & $69.1 \mathrm{bB}$ & $78.2 \mathrm{aA}$ & $158 \mathrm{bB}$ & $217 \mathrm{aA}$ & $72 \mathrm{bC}$ & $106 \mathrm{aC}$ & $45.4 \mathrm{aB}$ & $49.9 \mathrm{aA}$ & $10.3 \mathrm{aB}$ & $9.2 \mathrm{bB}$ & $1.49 \mathrm{aA}$ & $1.17 \mathrm{bB}$ \\
\hline TSKC $\times$ CTRK -001 & $71.6 \mathrm{aB}$ & $72.3 \mathrm{aB}$ & $202 \mathrm{aA}$ & $179 \mathrm{aC}$ & $93 \mathrm{aB}$ & $85 \mathrm{aD}$ & $46.3 \mathrm{aB}$ & $47.6 \mathrm{aA}$ & $9.7 \mathrm{aC}$ & $9.3 \mathrm{aB}$ & $1.44 \mathrm{aA}$ & $1.32 \mathrm{aB}$ \\
\hline TSKC $\times$ CTTR -028 & $74.9 \mathrm{aA}$ & $75.0 \mathrm{aA}$ & $184 \mathrm{aA}$ & $191 \mathrm{aB}$ & $90 \mathrm{aB}$ & $98 \mathrm{aC}$ & $49.1 \mathrm{aB}$ & $51.2 \mathrm{aA}$ & $10.3 \mathrm{aB}$ & $8.8 \mathrm{bC}$ & $1.36 \mathrm{aB}$ & $1.17 \mathrm{bB}$ \\
\hline LVK $\times$ LCR-010 & $77.9 \mathrm{aA}$ & $77.5 \mathrm{aA}$ & $201 \mathrm{aA}$ & $203 \mathrm{aB}$ & $118 \mathrm{aA}$ & $107 \mathrm{aC}$ & $58.7 \mathrm{aA}$ & $53.7 \mathrm{aA}$ & $9.0 \mathrm{aC}$ & $8.4 \mathrm{aC}$ & $1.19 \mathrm{aB}$ & $1.17 \mathrm{aB}$ \\
\hline TSKC $\times$ TRBK-007 & $75.9 \mathrm{aA}$ & $76.9 \mathrm{aA}$ & $218 \mathrm{aA}$ & $198 \mathrm{aB}$ & $115 \mathrm{aA}$ & $108 \mathrm{aC}$ & $52.9 \mathrm{aA}$ & $54.8 \mathrm{aA}$ & $9.7 \mathrm{aC}$ & $8.5 \mathrm{bC}$ & $1.27 \mathrm{aB}$ & $1.32 \mathrm{aB}$ \\
\hline TSKC $\times$ CTQT1434-004 & $75.9 \mathrm{aA}$ & $78.3 \mathrm{aA}$ & $192 \mathrm{bA}$ & $218 \mathrm{aA}$ & $76 \mathrm{bC}$ & $118 \mathrm{aB}$ & $39.6 \mathrm{bB}$ & $54.3 \mathrm{aA}$ & $10.0 \mathrm{ab}$ & $9.4 \mathrm{aB}$ & $1.28 \mathrm{aB}$ & $1.28 \mathrm{aB}$ \\
\hline HTR-207 & $77.4 \mathrm{aA}$ & $79.5 \mathrm{aA}$ & $201 \mathrm{bA}$ & $230 \mathrm{aA}$ & $109 \mathrm{bA}$ & $136 \mathrm{aA}$ & $55.1 \mathrm{aA}$ & $59.1 \mathrm{aA}$ & $10.5 \mathrm{aB}$ & $10.4 \mathrm{aA}$ & $1.39 \mathrm{bB}$ & $1.57 \mathrm{aA}$ \\
\hline TSKC $\times$ TRDP-023 & $65.5 \mathrm{bC}$ & $74.8 \mathrm{aA}$ & $188 \mathrm{aA}$ & $190 \mathrm{aB}$ & $101 \mathrm{aB}$ & $98 \mathrm{aC}$ & $54.0 \mathrm{aA}$ & $51.7 \mathrm{aA}$ & $11.8 \mathrm{aA}$ & $9.4 \mathrm{bB}$ & $1.36 \mathrm{aB}$ & $1.31 \mathrm{aB}$ \\
\hline San Diego citrandarin & $69.1 \mathrm{bB}$ & $74.7 \mathrm{aA}$ & $192 \mathrm{aA}$ & $194 \mathrm{aB}$ & $92 \mathrm{aB}$ & $104 \mathrm{aC}$ & $48.0 \mathrm{aB}$ & $53.9 \mathrm{aA}$ & $11.4 \mathrm{aA}$ & $8.9 \mathrm{bC}$ & $1.35 \mathrm{aB}$ & $1.30 \mathrm{aB}$ \\
\hline General mean & \multicolumn{2}{|c|}{73.0} & \multicolumn{2}{|c|}{185.91} & \multicolumn{2}{|c|}{94.24} & \multicolumn{2}{|c|}{50.51} & \multicolumn{2}{|c|}{9.73} & \multicolumn{2}{|c|}{1.34} \\
\hline Coefficient of variation (\%) & \multicolumn{2}{|c|}{3.0} & \multicolumn{2}{|c|}{7.8} & \multicolumn{2}{|c|}{8.6} & \multicolumn{2}{|c|}{10.0} & \multicolumn{2}{|c|}{4.9} & \multicolumn{2}{|c|}{7.2} \\
\hline \multirow{3}{*}{$\mathrm{F}^{(2)}$} & \multicolumn{2}{|c|}{$28.07 * *$} & \multicolumn{2}{|c|}{$10.24 * *$} & \multicolumn{2}{|c|}{$21.37 * *$} & \multicolumn{2}{|c|}{$2.34^{\mathrm{ns}}$} & \multicolumn{2}{|c|}{$90.72 * *$} & \multicolumn{2}{|c|}{$11.48^{* *}$} \\
\hline & \multicolumn{2}{|c|}{$17.85^{* *}$} & \multicolumn{2}{|c|}{$13.33^{* *}$} & \multicolumn{2}{|c|}{$25.83^{* *}$} & \multicolumn{2}{|c|}{$4.30 * *$} & \multicolumn{2}{|c|}{$7.10 * *$} & \multicolumn{2}{|c|}{$6.49 * *$} \\
\hline & \multicolumn{2}{|c|}{$2.83 * *$} & & & & & & & & & & \\
\hline
\end{tabular}

${ }^{(1)}$ Values followed by equal letters, lowercase in the columns and uppercase in the rows, do not differ by the Scott-Knott test within $5 \%$ probability. ${ }^{(2)} \mathrm{F}$,

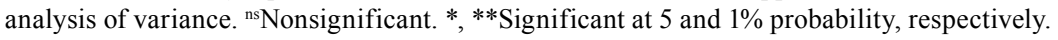


The rootstock TSKC $\times$ TRBK-007 had the most pronounced peel color, with the largest hue angle in both harvests (Table 5). The first year showed a greater variation of hue angle between the different rootstocks. When comparing the 2016 season to the 2015 one, TSKFL $\times$ CTTR-006, LVK $\times$ LCR-010, TSKC $\times$ CTQT1434-004, TSKC $\times$ TRDP-023, and the citrandarin 'San Diego' were observed for maintaining their color. Nonetheless, in the state of Ceará, Pereira et al. (2014) found high-hue angle values of $100 \mathrm{~h}^{\circ}$ for 'Valência Delta' oranges using the 'Swingle' citrumelo.

Variations were found across the different samples for the ascorbic acid content, whose highest values were observed for TSKC $\times$ CTRK-001 and TSKC $\times$ TRDP-

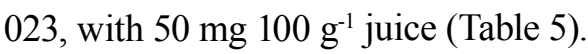

Therelative values of antioxidantcapacity and phenolic compound content decreased from the first to the second harvest (Table 5). The number of fruit per plant affected the orange quality, as a consequence of the source/ drain relationship that characterizes the distribution of photoassimilates to all fruit. The rootstocks HTR-207, TSKC $\times$ TRDP-023, and citrandarin 'San Diego' showed higher-antioxidant capacity than the other combinations across both harvests, with total productions of 5.1, 11.0, and $8.5 \mathrm{~kg}$ per plant, respectively, in 2016. The overall mean value of antioxidant activity across all tested combinations was 151.36 Trolox $\mathrm{g}^{-1}$ juice.

There was a significant variation for phenolic content between the different combinations (Table 5). TSKC $\times$ CTRK-001 and citrandarin 'San Diego' were associated with an elevated amount of bioactive compounds in the first harvest year. In a study of 'Clemenules' tangerines, Legua et al. (2014) found that the rootstock plays an important role in the determination of the concentration of phenolic compounds. In particular, they obtained $60 \mathrm{mg}$ gallic acid equivalent $100 \mathrm{~g}^{-1}$ when using the 'Volkameriano' lemon as a rootstock. However, in the 2015 harvest, TSKC $\times$ CTRK-001 and citrandarin 'San Diego' had 102.7 and $106.4 \mathrm{mg}$ gallic acid equivalent 100 $\mathrm{g}^{-1}$. This shows that these rootstocks provide to 'Valência' orange the capacity to produce greater quantities of phenolic compounds, increasing the health potential that fruit can offer due to their antioxidant activity.

Table 5. Physicochemical and phytochemical characteristics of the 'Valência' orange (Citrus sinensis) combined with 13 rootstocks in the 2015 and 2016 harvests, in the municipality of Pelotas, in the state of Rio Grande do Sul, Brazil ${ }^{(1)}$.

\begin{tabular}{|c|c|c|c|c|c|c|c|c|c|c|}
\hline \multirow[t]{2}{*}{ Rootstock } & \multicolumn{2}{|c|}{$\begin{array}{l}\text { Soluble solid/acidity } \\
\text { ratio }\end{array}$} & \multicolumn{2}{|c|}{$\begin{array}{l}\text { Peel color } \\
\text { Hue angle }\end{array}$} & \multicolumn{2}{|c|}{$\begin{array}{l}\text { Ascorbic acid } \\
\mathrm{mg} 100 \mathrm{~g}^{-1}\end{array}$} & \multicolumn{2}{|c|}{$\begin{array}{c}\text { Antioxidant capacity } \\
\text { Trolox } \mathrm{g}^{-1}\end{array}$} & \multicolumn{2}{|c|}{$\begin{array}{l}\text { Phenolic compounds } \\
\text { gallic acid } 100 \mathrm{~g}^{-1}\end{array}$} \\
\hline & 2015 & 2016 & 2015 & 2016 & 2015 & 2016 & 2015 & 2016 & 2015 & 2016 \\
\hline TSKC $\times$ CTQT1439-035 & $6.17 \mathrm{aB}$ & $5.41 \mathrm{aC}$ & $72.6 \mathrm{bC}$ & $75.8 \mathrm{aA}$ & $47.5 \mathrm{aA}$ & $46.7 \mathrm{aB}$ & $160 \mathrm{aB}$ & $121 \mathrm{bB}$ & $82.6 \mathrm{aC}$ & $70.8 \mathrm{bA}$ \\
\hline TSKC $\times$ TRDP-026 & $7.09 \mathrm{aB}$ & $8.18 \mathrm{aA}$ & $73.3 \mathrm{aC}$ & $74.0 \mathrm{aB}$ & $45.0 \mathrm{aB}$ & $45.7 \mathrm{aB}$ & $174 \mathrm{aB}$ & $119 \mathrm{bB}$ & $87.4 \mathrm{aC}$ & $70.2 \mathrm{bA}$ \\
\hline HTR-206 & 7.61aA & $7.36 \mathrm{aA}$ & $71.5 \mathrm{bC}$ & $73.9 \mathrm{aB}$ & $41.6 \mathrm{bB}$ & $46.7 \mathrm{aB}$ & $173 \mathrm{aB}$ & $117 \mathrm{bB}$ & $87.9 \mathrm{aC}$ & $70.6 \mathrm{bA}$ \\
\hline HTR-208 & $7.06 \mathrm{aB}$ & $7.67 \mathrm{aA}$ & $72.0 \mathrm{bC}$ & $75.0 \mathrm{aB}$ & $48.1 \mathrm{aA}$ & $44.7 \mathrm{aB}$ & $196 \mathrm{aA}$ & $111 \mathrm{bB}$ & $98.1 \mathrm{aB}$ & $70.2 \mathrm{bA}$ \\
\hline TSKFL $\times$ CTTR -006 & $6.95 \mathrm{aB}$ & $7.92 \mathrm{aA}$ & $76.1 \mathrm{aB}$ & $75.3 \mathrm{aB}$ & $44.7 \mathrm{bB}$ & $48.7 \mathrm{aA}$ & $177 \mathrm{aB}$ & $108 \mathrm{bB}$ & $93.7 \mathrm{aB}$ & $64.2 \mathrm{bA}$ \\
\hline TSKC $\times$ CTRK -001 & $6.76 \mathrm{aB}$ & $7.04 \mathrm{aA}$ & $72.1 \mathrm{bC}$ & $75.9 \mathrm{aA}$ & $47.5 \mathrm{bA}$ & $51.0 \mathrm{aA}$ & $198 \mathrm{aA}$ & $115 \mathrm{bB}$ & $102.7 \mathrm{aA}$ & $70.7 \mathrm{bA}$ \\
\hline TSKC $\times$ CTTR -028 & $7.52 \mathrm{aA}$ & $7.56 \mathrm{aA}$ & $71.5 \mathrm{bC}$ & $76.5 \mathrm{aA}$ & $48.4 \mathrm{aA}$ & $41.7 \mathrm{bB}$ & $176 \mathrm{aB}$ & $108 \mathrm{bB}$ & $95.5 \mathrm{aB}$ & $59.4 \mathrm{bA}$ \\
\hline LVK $\times$ LCR -010 & $7.56 \mathrm{aA}$ & $7.29 \mathrm{aA}$ & $75.8 \mathrm{aB}$ & $76.9 \mathrm{aA}$ & $44.1 \mathrm{aB}$ & $46.7 \mathrm{aB}$ & $166 \mathrm{aB}$ & $119 \mathrm{bB}$ & $89.5 \mathrm{aC}$ & $72.2 \mathrm{bA}$ \\
\hline TSKC $\times$ TRBK -007 & $7.71 \mathrm{aA}$ & $6.39 \mathrm{bB}$ & $81.9 \mathrm{aA}$ & $77.2 \mathrm{bA}$ & $43.8 \mathrm{aB}$ & $44.7 \mathrm{aB}$ & $178 \mathrm{aB}$ & $143 \mathrm{bA}$ & $95.0 \mathrm{aB}$ & $67.5 \mathrm{bA}$ \\
\hline TSKC $\times$ CTQT1434-004 & $7.84 \mathrm{aA}$ & $7.34 \mathrm{aA}$ & $75.2 \mathrm{aB}$ & $75.9 \mathrm{aA}$ & $45.0 \mathrm{aB}$ & $43.7 \mathrm{aB}$ & $186 \mathrm{aA}$ & $124 \mathrm{bB}$ & $96.0 \mathrm{aB}$ & $67.0 \mathrm{bA}$ \\
\hline HTR-207 & $7.59 \mathrm{aA}$ & $6.68 \mathrm{aB}$ & $81.6 \mathrm{aA}$ & $75.0 \mathrm{bB}$ & $41.9 \mathrm{aB}$ & $44.7 \mathrm{aB}$ & $190 \mathrm{aA}$ & $130 \mathrm{bA}$ & $94.8 \mathrm{aB}$ & $69.0 \mathrm{bA}$ \\
\hline TSKC $\times$ TRDP-023 & $8.66 \mathrm{aA}$ & $6.99 \mathrm{bA}$ & $75.2 \mathrm{aB}$ & $74.8 \mathrm{aB}$ & $49.3 \mathrm{aA}$ & $51.0 \mathrm{aA}$ & $185 \mathrm{aA}$ & $118 \mathrm{bA}$ & $97.5 \mathrm{aB}$ & $67.7 \mathrm{bA}$ \\
\hline Citrandarin San Diego & $8.53 \mathrm{aA}$ & $6.85 \mathrm{bA}$ & $76.2 \mathrm{aB}$ & $75.9 \mathrm{aA}$ & $42.2 \mathrm{aB}$ & $44.7 \mathrm{aB}$ & $210 \mathrm{aA}$ & $146 \mathrm{bA}$ & $106.4 \mathrm{aA}$ & $74.9 \mathrm{bA}$ \\
\hline General mean & \multicolumn{2}{|c|}{7.30} & \multicolumn{2}{|c|}{75.33} & \multicolumn{2}{|c|}{45.79} & \multicolumn{2}{|c|}{151.36} & \multicolumn{2}{|c|}{81.18} \\
\hline Coefficient of variation (\%) & \multicolumn{2}{|c|}{9.2} & \multicolumn{2}{|c|}{1.3} & \multicolumn{2}{|c|}{4.4} & \multicolumn{2}{|c|}{7.5} & \multicolumn{2}{|c|}{6.2} \\
\hline \multirow{3}{*}{ rootstock $\times$ har } & \multicolumn{2}{|c|}{$4.29 *$} & \multicolumn{2}{|c|}{$10.93 * *$} & \multicolumn{2}{|c|}{$1.47 * *$} & \multicolumn{2}{|c|}{$589.8 * *$} & \multicolumn{2}{|c|}{$497.49 * *$} \\
\hline & \multicolumn{2}{|c|}{$3.35 * *$} & \multicolumn{2}{|c|}{$14.48^{* *}$} & \multicolumn{2}{|c|}{$5.80 * *$} & \multicolumn{2}{|c|}{$5.28^{* *}$} & \multicolumn{2}{|c|}{$3.90 * *$} \\
\hline & \multicolumn{2}{|c|}{$2.66^{*}$} & \multicolumn{2}{|c|}{$19.45^{* *}$} & \multicolumn{2}{|c|}{$3.99 * *$} & \multicolumn{2}{|c|}{$2.30^{*}$} & \multicolumn{2}{|c|}{$3.70 * *$} \\
\hline
\end{tabular}

${ }^{(1)}$ Values followed by equal letters, lowercase in the columns and uppercase in the rows, do not differ by the Scott-Knott test within $5 \%$ probability. ${ }^{(2)} \mathrm{F}$,

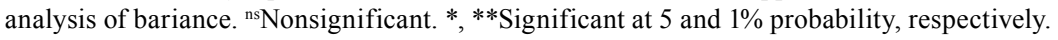




\section{Conclusions}

1. The rootstocks TSKC $\times$ TRDP-026 and TSKC $\times$ CTQT1434-004 encourage the development of 'Valência' orange scion, and increase its productive precocity in initial harvest years in the soil and climactic conditions of Rio Grande do Sul state.

2. The rootstock TSKC $\times$ TRDP-023 provides fruit with high levels of soluble solids, titratable acid, color, and ascorbic acid; and the rootstock citrandarin 'San Diego' offers fruit with improved color and phenolic compound content for 'Valência' oranges in early stages of production, under the soil and climactic conditions of Rio Grande do Sul.

\section{Acknowledgments}

To Coordenação de Aperfeiçoamento de Pessoal de Nível Superior (Capes), for scholarship granted; to Empresa Brasileira de Pesquisa Agropecuária (Embrapa), for financial support; and to Dr. José Carlos Fachinello, for providing a valuable guidance.

\section{References}

AULER, P.A.M.; FIORI-TUTIDA, A.C.G.; SCHOLTZ, M.B. dos S. Qualidade industrial e maturação de frutos de laranjeira 'Valência' sobre seis porta-enxertos. Revista Brasileira de Fruticultura, v.31, p.1158-1167, 2009. DOI: https://doi.org/10.1590/S0100-29452009000400033.

AULER, P.A.M.; FIORI-TUTUDA, A.C.G.; TAZIMA, Z.H. Comportamento da laranjeira 'Valência' sobre seis porta-enxertos no Nordeste do Paraná. Revista Brasileira de Fruticultura, v.30, p.229-234, 2008. DOI: https://doi.org/10.1590/S010029452008000100042 .

BARBASSO, D.V.; PEDRO JÚNIOR, M.J.; PIO, R.M. Caracterização fenológica de variedades do tipo Murcott em três porta-enxertos. Revista Brasileira de Fruticultura, v.27, p.399403, 2005. DOI: https://doi.org/10.1590/S0100-29452005000300015.

BRAND-WILLIAMS, W.; CUVELIER, M.E.; BERSET, C. Use of a free radical method to evaluate antioxidant activity. Food Science and Technology, v.28, p.25-30, 1995. DOI: https://doi.org/10.1016/S0023-6438(95)80008-5.

CARVALHO, L.M. de; CARVALHO, H.W.L. de; SOARES FILHO, W. dos S.; MARTINS, C.R.; PASSOS, O.S. Porta-enxertos promissores, alternativos ao limoeiro 'Cravo', nos Tabuleiros Costeiros de Sergipe. Pesquisa Agropecuária Brasileira, v.51, p.132-141, 2016. DOI: https://doi.org/10.1590/S0100204X2016000200005.
CUNHA SOBRINHO A.P. da; MAGALHÃES, A.F. de J.; SOUZA, A. da S.; PASSOS, O.S.; SOARES FILHO, W. dos S. (Ed.). Cultura dos citros. Brasília: Embrapa, 2013. v.1, 399p.

FALLAHI, E.; RODNEY, D.R. Tree size, yield, fruit quality, and leaf mineral nutrient concentration of 'Fairchild' mandarin on six rootstock. Journal of the American Society for Horticultural Science, v.117, p.28-31, 1992. DOI: https://doi.org/10.21273/JASHS.117.1.28.

FRANÇA, N. de O.; AMORIM, M. da S.; GIRARDI, E.A.; PASSOS, O.S.; SOARES FILHO, W. dos S. Performance of 'Tuxpan Valência' sweet orange grafted onto 14 rootstocks in northern Bahia, Brasil. Revista Brasileira de Fruticultura, v.38, p.e-684, 2016. DOI: https://doi.org/10.1590/0100-29452016684.

FUNDECITRUS. Fundo de Defesa da Citricultura. Relatório de atividades: junho/2016-maio/2017. 2017. Available at: <http:// www.fundecitrus.com.br/comunicacao/relatorios $>$. Accessed on: May 202017.

HORWITZ, W.; LATIMER JR., G.W. Official Methods of Analysis of AOAC International. $18^{\text {th }}$ ed. Gaithersburg: Association of Official Analytical Chemists, 2005. Official Method 945.08.

IBGE. Instituto Brasileiro de Geografia e Estatística. Banco de Dados Agregados. Sistema IBGE de Recuperação Automática - SIDRA. 2014. Available at: <http://www.sidra.ibge.gov.br>. Accessed on: May 102017.

INMET. Instituto Nacional de Meteorologia. BDMEP - Banco de Dados Meteorológicos para Ensino e Pesquisa. 2016. Available at: <http://www.inmet.gov.br/portal/index.php?r=bdmep/bdmep $>$. Accessed on: Dec 122016.

JACOBS, M.B. The chemical analysis of foods and food products. New York: Van Nostrand, 1958. 979p.

LEGUA, P.; FORNER, J.B.; HERNÁNDEZ, F.C.A.; FORNERGINER, M.A. Total phenolics, organic acids, sugars and antioxidant activity of mandarin (Citrus clementina Hort. Ex Tan.): variation from rootstock. Scientia Horticulturae, v.174, p.60-64, 2014. DOI: https://doi.org/10.1016/j.scienta.2014.05.004.

LEME JUNIOR, J.; MALAVOLTA, E. Determinação fotométrica do ácido ascórbico. Anais da Escola Superior de Agricultura Luiz de Queiroz, v.7, p.115-130, 1950. DOI: http://dx.doi.org/10.1590/S0071-12761950000100016.

PEREIRA, G. da S.; MACHADO, F.L. de C.; COSTA, J.M.C. da. Aplicação de recobrimento prolonga a qualidade pós-colheita de laranja 'Valência Delta' durante armazenamento ambiente. Revista Ciência Agronômica, v.45, p.520-527, 2014. DOI: https://doi.org/10.1590/S1806-66902014000300012.

POMPEU JUNIOR, J.; BLUMER, S. Híbridos de trifoliata como porta-enxertos para a laranjeira 'Valência'. Pesquisa Agropecuária Brasileira, v.44, p.701-705, 2009. DOI: https://doi.org/10.1590/S0100-204X2009000700008.

POMPEU JUNIOR, J.; BLUMER, S. Híbridos de trifoliata como porta-enxertos para laranjeira 'Pêra'. Pesquisa Agropecuária Tropical, v.44, p.9-14, 2014. DOI: https://doi.org/10.1590/S198340632014000100007. 
SANTOS, H.G. dos; JACOMINE, P.K.T.; ANJOS, L.H.C. dos; OLIVEIRA, V.A. de; OLIVEIRA, J.B. de; COELHO, M.R.; LUMBRERAS, J.F.; CUNHA, T.J.F. (Ed.). Sistema brasileiro de classificação de solos. 2.ed. Rio de Janeiro: Embrapa Solos, 2006. $306 \mathrm{p}$.

SCHÄFER, G.; BASTIANEL, M.; DORNELLES, A.C.C. Portaenxertos utilizados na citricultura. Ciência Rural, v.31, p.723-733, 2001. DOI: https://doi.org/10.1590/S0103-84782001000400028.
SWAIN, T;; HILLIS, W.E. The phenolic constituents of Prunus domestica. The quantitative analysis of phenolic constituents. Journal of the Science of Food and Agriculture, v.10, p.63-68, 1959. DOI: https://doi.org/10.1002/jsfa.2740100110.

ZENEBON, O.; PASCUET, N.S.; TIGLEA, P. (Coord.). Métodos físico-químicos para análise de alimentos. 4.ed. São Paulo: Instituto Adolfo Lutz, 2008. 1020p. 